\title{
PROTEIN-BINDING OF INORGANIC PHOSPHATE IN PLASMA OF NORMAL SUBJECTS AND PATIENTS WITH RENAL DISEASE*
}

\author{
By MACKENZIE WALSER WITH THE TECHNICAL ASSISTANCE OF MARY JANE FORD \\ AND SYLVIA BUTLER
}

(From the Department of Pharmacology and Experimental Therapeutics and the Department of Medicine, The Johns Hopkins University School of Medicine, Baltimore, Md.)

(Submitted for publication May 28, 1959; accepted November 19, 1959)

Despite a large amount of experimental data, it remains uncertain whether all of the plasma phosphate is filtrable through semipermeable membranes. Early micropuncture studies in Amphibia indicated that the concentration of inorganic phosphate in glomerular filtrate was the same as that in whole plasma $(1,2)$. If this is the case in mammals, approximately 17 per cent of the plasma phosphate may be nonfilterable. This follows from consideration of the normal plasma water content, $930 \mathrm{~g}$ per L, and the theoretical Donnan ratio for divalent anions, 0.90 to 0.91 (Reference 3, page 771). Since 80 per cent of the plasma phosphate consists of $\mathrm{HPO}_{4}{ }^{2-}$ and 20 per cent $\mathrm{H}_{2} \mathrm{PO}_{4}^{-}$, the effective Donnan factor for plasma phosphate should be 0.91 to 0.92 . The concentration of phosphate in ultrafiltrate would therefore be $1 / 0.93 \times 0.915$ or 1.175 times that in whole plasma.

Some of the pertinent reports are summarized in Table I. This list is not intended to be complete, and in particular omits the earliest observations, reported prior to 1926 . In those instances in which the plasma or serum values were reported without correction for water content, a correction was applied as described below. The ratio of phosphate concentration in ultrafiltrate or dialysate to that in plasma or serum water for the entire group averages 0.94. The theoretical value, representing complete filtrability, is 1.09. Only a few isolated samples have been found to show ratios of 1.09 or higher.

The only two studies in which the $\mathrm{pH}$ and temperature were the same as that of blood in vivo, References 6 and 8, revealed mean ratios of 0.85 and 0.89 , respectively. These studies both uti-

* This work was supported by a United States Public Health Service Research Grant (A-2306). lized measurements of saline solutions equilibrated with the circulating plasma.

It has also been reported that the filtrability of plasma phosphate may become markedly reduced when either plasma calcium or plasma phosphate is increased $(5,9,11)$. These observations have supported the concept of a nondiffusible calcium phosphate complex. However, this substance is thought to be present only in abnormal plasma.

Toribara, Terepka and Dewey (13) have shown that the filtrability of plasma calcium is influenced by the $\mathrm{pH}$ and temperature at which ultrafiltration is performed. Phosphate analyses of ultrafiltrates prepared at body temperature and normal plasma $\mathrm{pH}$ have not been reported. The reported data (Table I) are for the most part based upon small series and exhibit considerable scatter. The filtrability of phosphate in uremic plasma has apparently not been studied. The occurrence of a "colloidal" calcium phosphate complex might be anticipated under these conditions, since hyperphosphatemia is often pronounced.

For these reasons, ultrafiltration was carried out at $37^{\circ} \mathrm{C}$ in an atmosphere of 5 per cent $\mathrm{CO}_{2}$ and 95 per cent $\mathrm{O}_{2}$, using plasma samples from normal subjects and from patients with azotemia. The results indicate that a significant fraction of the plasma inorganic phosphate is apparently bound to proteins. This binding is not dependent upon plasma calcium or magnesium. In azotemic patients without phosphate retention, protein-binding of phosphate is the same as in normal subjects. In the presence of phosphate retention, no evidence was found for a decrease in the filtrability of phosphate. On the contrary, the percentage of phosphate bound to protein did not differ significantly from normal. 
TABLE I

Ratios of the concentration of phosphate in ultrafiltrate or dialysate to that in plasma or serum water in reported studies on normal humans and dogs

\begin{tabular}{|c|c|c|c|c|}
\hline Authors & $\begin{array}{l}\text { No. and } \\
\text { species }\end{array}$ & Method & Range & Mean \\
\hline$\underset{1926}{\text { Pincus et al. (4) }}$ & 6 Dogs & Ultrafiltration & $0.90-1.10$ & 1.01 \\
\hline $\begin{array}{l}\text { Grollman (5) } \\
1927\end{array}$ & 7 Dogs & Ultrafiltration & $1.00-1.00$ & 1.00 \\
\hline $\begin{array}{l}\text { Greene and Power (6) } \\
\quad 1931\end{array}$ & 14 Dogs & Dialysis in vivo & $0.54-1.11$ & 0.85 \\
\hline $\begin{array}{l}\text { Benjamin and Hess (7) } \\
\quad 1933\end{array}$ & $\begin{array}{l}21 \text { Humans } \\
73 \text { Dogs } \\
25 \text { Rats }\end{array}$ & $\begin{array}{l}\text { Ultrafiltration } \\
\text { Ultrafiltration } \\
\text { Ultrafiltration }\end{array}$ & $\begin{array}{l}\text { Not given } \\
\text { Not given } \\
\text { Not given }\end{array}$ & $\begin{array}{l}0.97 \\
0.94 \\
0.93\end{array}$ \\
\hline $\begin{array}{l}\text { Cantarow and Haury (8) } \\
1939\end{array}$ & 6 Dogs & Vividiffusion & $0.85-0.95$ & 0.89 \\
\hline $\begin{array}{l}\text { Harrison and Harrison (9) } \\
\quad 1941\end{array}$ & 6 Dogs & Ultrafiltration & $0.87-0.93$ & 0.91 \\
\hline $\begin{array}{l}\text { Smith et al. (10) } \\
\quad 1943\end{array}$ & 13 Humans & Ultrafiltration & $0.97-1.08$ & 0.96 \\
\hline $\begin{array}{l}\text { Hopkins et al. (11) } \\
\quad 1952\end{array}$ & 6 Humans & Ultrafiltration & $0.90-1.09$ & 0.99 \\
\hline$\underset{1955}{\text { Foulks }}$ & 5 Dogs & Ultrafiltration & $0.79-0.88$ & 0.85 \\
\hline
\end{tabular}

\section{METHODS}

Venous blood was obtained in oiled syringes wet with heparin solution, and separated without exposure to air. Ultrafiltration was carried out by the method of Toribara and associates (13). Plasma $\mathrm{pH}$, measured before and after ultrafiltration, did not change more than 0.05 unit. Phosphate was determined on trichloroacetic acid filtrates of plasma and on ultrafiltrates by the method of Fiske and Subbarow (14). The recovery of phosphate added to plasma or ultrafiltrate averaged 100 per cent. Protein determinations were performed by the biuret method (15). Plasma water content, in grams per liter, was approximated as 990 minus 8 [Prot], where [Prot] represents the protein concentration in grams per cent (3).

In order to determine whether equilibrium across the cellophane membrane persisted during ultrafiltration, several types of experiments were performed. 1) Phosphate concentrations were compared in the fluid formed during the first half hour of ultrafiltration, representing approximately 15 per cent of the volume of plasma used, and during the ensuing three hours, at the end of which the volume of plasma remaining was about onehalf of the original volume. In four normal samples, the ratios of phosphate concentrations in the first portion to the last portion were $0.99,0.97,0.98$, and 0.97 . 2) Ultrafiltrates of normal plasma were subjected to ultrafiltration again, one-half of the total volume passing through the casing. The concentration of phosphate in the newly formed ultrafiltrate was, on the average, 3 per cent less than that in the original ultrafiltrate.

3) Ultrafiltrates were prepared from a solution of sodium

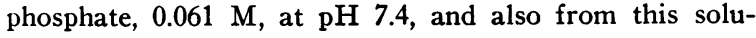
tion diluted 20-fold with isotonic saline. Again, centrifugation was continued until one-half of the total volume used had passed out of the sac. The phosphate concentration in these ultrafiltrates was, on the average, 2 per cent lower than in the original solutions. 4) Normal plasma samples were dialyzed against their own ultrafiltrates. This was done by filling a sac prepared from Visking casing with plasma obtained anaerobically, plus a small amount of mercury. This sac was inserted into a tube containing an equal volume of ultrafiltrate, plus a small amount of mercury. The tube was closed with a stopper, into which a needle was inserted in order to remove entrapped air. The needle was removed, and the tube was then rocked mechanically in a constant temperature bath at $37^{\circ} \mathrm{C}$ for six hours. The concentration of phosphate in ultrafiltrates of normal plasma was unchanged by this process.

All of the above results lend support to the conclusion that the method of ultrafiltration yields a valid sample of fluid in equilibrium with whole plasma. Deviations from equilibrium are so small that they lie within the experimental error.

\section{RESULTS}

The results of 24 determinations performed in 15 normal subjects and in 4 normal dogs are shown in Table II.

The ratio of phosphate concentration in ultrafiltrate to that in plasma water in the human sub- 
jects averaged 0.825 . As indicated above, if all of the phosphate were ultrafilterable, the ratio should be $1: 0.915$ or approximately 1.09 . The filtrable inorganic phosphate of plasma therefore comprises $0.825: 1.09$ or 76 per cent of the total.

The assumption that ultrafiltrate phosphate equals plasma phosphate entails only a small error, because it ignores corrections for Donnan factor and water content. In this series of subjects, the ratio of ultrafiltrate phosphate to plasma phosphate (uncorrected for water content) averages 0.89 .

In Table III are shown the results of observations in a series of patients with renal disease. Although all of these subjects had signs of renal damage, in many the degree of azotemia was slight. Consequently phosphate retention was present in only 21 of the 32 patients. The highest plasma phosphate observed was 5.32 mmoles per $\mathrm{L}$ or $16.5 \mathrm{mg}$ per $100 \mathrm{ml}$.

In the patients without phosphate retention, the ratio of ultrafiltrate phosphate to plasma water phosphate averaged 0.866 , a value which does not differ significantly from the normal mean of 0.825 . In the patients with phosphate retention, this ratio averaged 0.889 , which also is not significantly greater than the normal mean. Thus the absolute quantity of phosphate bound is increased approximately in proportion to the rise in plasma phosphate. For example, in the five plasma samples containing 3 to 4 mmoles per $\mathrm{L}$ of phosphate, the average filtrate phosphate is 3.14 mmoles per L. Applying a Donnan factor of 0.915 , the free phosphate in plasma water becomes 2.87 mmoles per $\mathrm{L}$. Total phosphate in plasma water averages 3.32 mmoles per $\mathrm{L}$. Therefore bound phosphate is 3.32 to 2.87 or 0.45 mmoles per L, or 14 per cent of the total. In the normal subjects similar calculation reveals that an average of 0.31 mmoles per $\mathrm{L}$, or 25 per cent, of the total phosphate is bound. The differ-

TABLE II

Protein-binding of inorganic phosphate (normal subjects)*

\begin{tabular}{|c|c|c|c|c|c|c|}
\hline & Subject & {$[\text { Protein }]_{\mathrm{P}}$} & {$[\mathrm{Pi}] \mathrm{P}$} & {$[\mathrm{Pi}]_{\mathrm{PW}}$} & {$[\mathrm{Pi}] \mathrm{UF}$} & $\underset{[\mathrm{Pi}] \mathrm{UF} /[\mathrm{Pi}] \mathrm{PW}}{\text { Ratio }}$ \\
\hline Normal dogs & $\begin{array}{l}\text { A } \\
\text { B } \\
\text { C } \\
\text { D }\end{array}$ & $\begin{array}{l}g m \% \\
6.4 \\
6.6 \\
6.2 \\
6.7\end{array}$ & $\begin{array}{c}\text { mmoles } / L \\
1.89 \\
1.18 \\
1.26 \\
1.57\end{array}$ & $\begin{array}{c}\text { mmoles } / L \\
2.02 \\
1.26 \\
1.34 \\
1.68\end{array}$ & $\begin{array}{c}\text { mmoles/L } \\
1.61 \\
1.15 \\
1.29 \\
1.24\end{array}$ & $\begin{array}{rr} & 0.80 \\
& 0.91 \\
& 0.96 \\
& 0.74 \\
\text { Mean } & 0.85\end{array}$ \\
\hline Normal men & $\begin{array}{l}\text { MW } \\
\text { MW } \\
\text { MW } \\
\text { MW } \\
\text { IW } \\
\text { IW } \\
\text { GM } \\
\text { DS } \\
\text { LL } \\
\text { JB } \\
\text { KG }\end{array}$ & $\begin{array}{l}6.5 \\
7.2 \\
7.2 \\
6.6 \\
7.2 \\
6.9 \\
7.6 \\
7.7 \\
6.5 \\
6.3 \\
6.5\end{array}$ & $\begin{array}{l}0.74 \\
1.15 \\
1.13 \\
1.22 \\
0.79 \\
0.88 \\
1.43 \\
1.04 \\
1.30 \\
1.52 \\
1.07\end{array}$ & $\begin{array}{l}0.79 \\
1.23 \\
1.21 \\
1.30 \\
0.85 \\
0.94 \\
1.54 \\
1.12 \\
1.39 \\
1.62 \\
1.14\end{array}$ & $\begin{array}{l}0.69 \\
0.96 \\
0.96 \\
0.98 \\
0.74 \\
0.84 \\
1.38 \\
1.00 \\
1.15 \\
1.44 \\
1.09\end{array}$ & $\begin{array}{l}0.87 \\
0.78 \\
0.78 \\
0.75 \\
0.75 \\
0.89 \\
0.90 \\
0.89 \\
0.83 \\
0.89 \\
0.96\end{array}$ \\
\hline Normal women & $\begin{array}{l}\text { GK } \\
\text { GK } \\
\text { JS } \\
\text { JS } \\
\text { MF } \\
\text { BC } \\
\text { MS } \\
\text { RC } \\
\text { MM } \\
\text { SB }\end{array}$ & $\begin{array}{l}7.6 \\
6.6 \\
8.0 \\
6.3 \\
7.1 \\
7.2 \\
8.9 \\
6.5 \\
6.6 \\
7.3\end{array}$ & $\begin{array}{l}0.96 \\
0.99 \\
1.38 \\
1.28 \\
1.14 \\
1.26 \\
1.21 \\
1.45 \\
0.88 \\
1.16\end{array}$ & $\begin{array}{l}1.03 \\
1.06 \\
1.49 \\
1.36 \\
1.22 \\
1.35 \\
1.33 \\
1.55 \\
0.94 \\
1.24\end{array}$ & $\begin{array}{l}0.80 \\
0.86 \\
1.04 \\
1.22 \\
1.04 \\
1.03 \\
0.97 \\
1.27 \\
0.76 \\
1.07\end{array}$ & $\begin{array}{l}0.78 \\
0.81 \\
0.70 \\
0.90 \\
0.85 \\
0.76 \\
0.73 \\
0.82 \\
0.81 \\
0.86\end{array}$ \\
\hline & & & & & Mean & $0.825 \pm 0.066(\mathrm{SD})$ \\
\hline
\end{tabular}

* $[\mathrm{Pi}]_{\mathrm{P}}=$ inorganic phosphate concentration in plasma; $[\mathrm{Pi}]_{\mathrm{PW}}=$ inorganic phosphate concentration in plasma water $;[\mathrm{Pi}] \mathrm{UF}=$ inorganic phosphate concentration in plasma ultrafiltrate. 
TABLE III

Protein-binding of inorganic phosphate in patients with azotemia*

\begin{tabular}{|c|c|c|c|c|c|c|}
\hline & Subject & {$[\text { Protein }]_{P}$} & {$[\mathrm{Pi}]_{\mathbf{P}}$} & {$[\mathrm{Pi}]_{\mathrm{PW}}$} & {$[\mathrm{Pi}]_{\mathrm{UF}}$} & $\underset{[\mathrm{Pi}]]_{\mathrm{UF} /[\mathrm{Pi}}^{\text {Ratio }}}{\mathrm{PW}_{\mathrm{PW}}}$ \\
\hline $\begin{array}{l}\text { Patients with- } \\
\text { out phosphate } \\
\text { retention }\end{array}$ & $\begin{array}{l}\text { Jon } \\
\text { Gre } \\
\text { Sis } \\
\text { Bar } \\
\text { Sim } \\
\text { Ste } \\
\text { Wil } \\
\text { Dil } \\
\text { Kin } \\
\text { Hew } \\
\text { Spe }\end{array}$ & $\begin{array}{l}g m \% \\
6.6 \\
6.5 \\
7.3 \\
7.4 \\
7.0 \\
7.3 \\
6.2 \\
6.6 \\
7.8 \\
8.1 \\
6.6\end{array}$ & $\begin{array}{c}\text { mmoles/L } \\
1.07 \\
1.12 \\
1.27 \\
1.32 \\
1.33 \\
1.43 \\
1.41 \\
1.46 \\
1.45 \\
1.49 \\
1.54\end{array}$ & $\begin{array}{c}\text { mmoles } / L \\
1.14 \\
1.20 \\
1.36 \\
1.42 \\
1.42 \\
1.53 \\
1.50 \\
1.56 \\
1.56 \\
1.61 \\
1.64\end{array}$ & $\begin{array}{c}\text { mmoles/L } \\
0.99 \\
1.03 \\
1.19 \\
1.27 \\
1.30 \\
1.32 \\
1.26 \\
1.28 \\
1.41 \\
1.26 \\
1.50\end{array}$ & $\begin{array}{l}0.87 \\
0.86 \\
0.88 \\
0.89 \\
0.92 \\
0.86 \\
0.84 \\
0.82 \\
0.90 \\
0.78 \\
0.91\end{array}$ \\
\hline $\begin{array}{l}\text { Patients with } \\
\text { phosphate re- } \\
\text { tention }\end{array}$ & $\begin{array}{l}\text { New } \\
\text { Sta } \\
\text { Wil } \\
\text { Edw } \\
\text { Mor } \\
\text { Lin } \\
\text { Jac } \\
\text { Sta } \\
\text { Bro } \\
\text { Har } \\
\text { Fis } \\
\text { Ree } \\
\text { Dav } \\
\text { Goo } \\
\text { Wav } \\
\text { Edw } \\
\text { Jac } \\
\text { She } \\
\text { Dis } \\
\text { Seg } \\
\text { Hie }\end{array}$ & $\begin{array}{l}5.5 \\
5.9 \\
7.0 \\
6.0 \\
5.7 \\
6.3 \\
5.7 \\
6.8 \\
6.6 \\
6.2 \\
5.7 \\
4.3 \\
6.6 \\
5.7 \\
6.9 \\
5.7 \\
5.8 \\
6.2 \\
5.5 \\
6.4 \\
7.4\end{array}$ & $\begin{array}{l}1.61 \\
1.67 \\
1.71 \\
1.75 \\
1.71 \\
1.82 \\
1.81 \\
1.80 \\
1.80 \\
1.97 \\
2.05 \\
2.28 \\
2.43 \\
2.79 \\
3.02 \\
3.14 \\
3.18 \\
3.48 \\
3.44 \\
5.07 \\
5.32\end{array}$ & $\begin{array}{l}1.70 \\
1.77 \\
1.85 \\
1.86 \\
1.81 \\
1.94 \\
1.91 \\
1.92 \\
1.92 \\
2.10 \\
2.17 \\
2.38 \\
2.59 \\
2.95 \\
3.23 \\
3.32 \\
3.38 \\
3.70 \\
3.64 \\
5.39 \\
5.72\end{array}$ & $\begin{array}{l}\text { Mean } \\
1.47 \\
1.60 \\
1.57 \\
1.71 \\
1.52 \\
1.74 \\
1.78 \\
1.64 \\
1.68 \\
1.80 \\
1.92 \\
2.07 \\
2.30 \\
2.57 \\
3.05 \\
3.05 \\
3.03 \\
3.36 \\
3.08 \\
5.23 \\
5.14\end{array}$ & $\begin{array}{c}0.866 \pm 0.041(\mathrm{SD}) \\
0.86 \\
0.90 \\
0.85 \\
0.92 \\
0.84 \\
0.90 \\
0.93 \\
0.86 \\
0.88 \\
0.86 \\
0.88 \\
0.87 \\
0.89 \\
0.87 \\
0.94 \\
0.92 \\
0.90 \\
0.91 \\
0.84 \\
0.97 \\
0.90\end{array}$ \\
\hline & & & & & Mean & $0.889 \pm 0.034(\mathrm{SD})$ \\
\hline
\end{tabular}

* Symbols as in Table II.

ence in protein concentration between the two groups was minor. ${ }^{1}$

In order to determine whether some form of interaction with calcium is involved in the apparent protein-binding of phosphate, the trisodium salt of ethylenediaminetetraacetic acid (EDTA) was added to plasma before ultrafiltration. Five $\mathrm{ml}$ of plasma was mixed with $0.2 \mathrm{ml}$ of EDTA solution, (adjusted to $\mathrm{pH} 7.4$ ) and ultrafiltered. This amount of EDTA is sufficient to complex the entire amount of calcium and magnesium present. The concentration of phosphate in this ultrafiltrate was compared to that in ultrafiltrate from

1 It is possible that hyperlipemia, with a consequent decrease in plasma water content, might account for part of the apparent increase in this ratio in renal failure. However, none of the subjects had the nephrotic syndrome or frankly lipemic plasma. the same plasma diluted with saline instead of EDTA solution. No difference was noted in three experiments. These results indicate that the protein-binding of phosphate in normal plasma is not dependent upon the presence of calcium or magnesium.

\section{DISCUSSION}

The results of this study indicate that a significant portion of the inorganic phosphate of plasma is not filtrable through cellophane. In normal subjects, this moiety amounts to about one-fourth of the total plasma inorganic phosphate; in patients with renal disease and phosphate retention, it is a somewhat smaller fraction. The probable explanation of these findings is protein-binding. It is also conceivable that phosphate might exist in plasma in a nondiffusible form without being 
bound to protein, calcium or magnesium. However, there is no evidence for such a compound at present. Govaerts (16) reported that a portion of the plasma phosphate does not exchange readily with administered radiophosphate. As Handler and Cohn (17) have shown, the specific activity of urinary phosphate is equal to that of plasma phosphate during a constant infusion of radiophosphate. These authors suggested that urinary delay time, or exchange with a pool of inorganic phosphate in the tubular epithelium, may account for the findings of Govaerts. It is also possible, however, that the exchange of administered radiophosphate with protein-bound phosphate may be significantly slower than with the filtrable portion of plasma phosphate.

We have not investigated the filtrability of phosphate in the presence of hypercalcemia. Others $(5,11)$ have reported that a nonfiltrable calcium phosphate complex is formed under these conditions. In normal plasma, the data presented here indicate that the protein-binding of phosphate is not dependent upon the presence of calcium or magnesium.

The present results probably do not alter the conclusions of the numerous studies pertaining to renal tubular reabsorption of phosphate in man and dogs. In most of these studies, it has been assumed that phosphate concentration in the glomerular filtrate is equal to phosphate concentration in plasma water. As indicated above, this assumption entails an error of 15 to 20 per cent in normal subjects, and less in patients with renal disease. The possibility also remains that the filtrability of phosphate at the glomerulus may differ from that indicated by cellophane membranes.

The theoretical Donnan ratio, $1 / \mathrm{r}^{2}$, as calculated by Van Slyke, Wu and McLean (3), is approximately 1.10 at normal $\mathrm{pH}$ and protein concentration. This is the factor which has been employed herein, in order to estimate the free phosphate ion concentration in whole plasma. As Manery (18) has pointed out, the observed Donnan ratios for various ions in plasma are all less that this theoretical value. The deviation is very small in the case of sodium and potassium but greater in the case of chloride, sulfate (19), ferrocyanide (20) and phosphate. Purified proteins bind virtually all anions which have been studied
$(21,22)$. It seems reasonable to infer, therefore, that free phosphate ions in plasma are distributed across semipermeable membranes in accordance with the theoretical factor, and that the remainder of plasma phosphate is bound to protein.

\section{SUM MARY}

Ultrafiltrates were prepared at $37^{\circ} \mathrm{C}$ in an atmosphere of 5 per cent $\mathrm{CO}_{2}$ from plasma samples obtained from 4 dogs, 15 normal men and women, and from 32 patients with varying degrees of azotemia. In the normal subjects, an average of one-fourth of the inorganic phosphate of plasma was found to be protein-bound. This binding was not dependent upon the presence of calcium or magnesium.

In patients with azotemia, with or without phosphate retention, the fraction of plasma inorganic phosphate bound to protein was not significantly different.

\section{REFERENCES}

1. Walker, A. M. Quantitative studies of the composition of glomerular urine. $\mathrm{X}$. The concentration of inorganic phosphate in glomerular urine from frogs and Necturi determined by an ultramicromodification of the Bell-Doisy method. J. biol. Chem. 1933, $101,239$.

2. White, H. L. Further observations on glomerular function. Amer. J. Physiol. 1932, 102, 222.

3. Van Slyke, D. D., Wu, H., and McLean, F. C. Studies of gas and electrolyte equilibria in the blood. V. Factors controlling the electrolyte and water distribution in the blood. J. biol. Chem. 1923, 56, 765, 771.

4. Pincus, J. B., Peterson, H. A., and Kramer, B. A study by means of ultrafiltration of the condition of several inorganic constituents of blood serum in disease. J. biol. Chem. 1926, 68, 601.

5. Grollman, A. The condition of the inorganic phosphorus of the blood with special reference to the calcium concentration. J. biol. Chem. 1927, 72, 565.

6. Greene, C. H., and Power, M. H. The distribution of electrolytes between serum and the in vivo dialysate. J. biol. Chem. 1931, 91, 183.

7. Benjamin, H. R., and Hess, A. F. The forms of the calcium and inorganic phosphorus in human and animal sera. I. Normal, rachitic, hypercalcemic, and other conditions. J. biol. Chem. 1933, 100, 27.

8. Cantarow, A., and Haury, V. G. Diffusion of calcium, magnesium and phosphorus into the peritoneum. Amer. J. Physiol. 1939, 126, 66.

9. Harrison, H. E., and Harrison, H. C. The renal excretion of inorganic phosphate in relation to the action of vitamin $\mathrm{D}$ and parathyroid hormone. J. clin. Invest. 1941, 20, 47. 
10. Smith, P. K., Ollayos, R. W., and Winkler, A. W. Tubular reabsorption of phosphate in the dog. $\mathrm{J}$. clin. Invest. 1943, 22, 143.

11. Hopkins, T., Howard, J. E., and Eisenberg, H. U1trafiltration studies on calcium and phosphorus in human serum. Johns Hopk. Hosp. Bull. 1952, 91, 1.

12. Foulks, J. G. Homeostatic adjustment in the renal tubular transport of inorganic phosphate in the dog. Canad. J. Biochem. 1955, 33, 638.

13. Toribara, T. Y., Terepka, A. R., and Dewey, P. A. The ultrafiltrable calcium of human serum. I. Ultrafiltration methods and normal values. J. clin. Invest. 1957, 36, 738.

14. Fiske, C. H., and Subbarow, Y. The colorimetric determination of phosphorus. J. biol. Chem. $1925,66,375$.

15. Wolfson, W. Q., Cohn, C., Calvary, E., and Ichiba, F. Studies in serum proteins. V. A rapid procedure for the estimation of total protein, true albumin, total globulin, alpha globulin, beta globulin, and gamma globulin in $1.0 \mathrm{ml}$. of serum. Amer. J. clin. Path. 1948, 18, 723.
16. Govaerts, J. Urinary excretion of phosphate with ${ }_{12}^{35} \mathrm{P}$ as an indicator. Nature (Lond.) 1947, 160, 53.

17. Handler, P. and Cohn, D. V. Use of radiophosphorus in studies of glomerular permeability of plasma inorganic phosphate. Amer. J. Physiol. 1951, 164, 646.

18. Manery, J. F. Water and electrolyte metabolism. Physiol. Rev. 1954, 34, 334.

19. Swan, R. C., Feinstein, H. M., and Madisso, H. Distribution of sulfate ion across semi-permeable membranes. J. clin. Invest. 1956, 35, 607.

20. Kleeman, C. R., and Epstein, F. H. Fate and distribution of $\mathrm{Fe}^{\infty}$ labeled ferrocyanide in humans and dogs. Proc. Soc. exp. Biol. (N. Y.) 1956, 93, 228.

21. Scatchard, G., Hughes, W. L., Jr., Gurd, F. R. N., and Wilcox, P. E. The interaction of proteins with small molecules and ions in Chemical Specificity in Biological Interactions, F. R. N. Gurd, Ed. New York, Academic Press Inc., 1954, p. 193.

22. Edsall, J. T., and Wyman, J., Eds. Biophysical Chemistry. New York, Academic Press Inc., 1958. vol. I, pp. 321, 650. 